Article

\title{
On the Selective Transport of Nutrients through Polymer Inclusion Membranes Based on Ionic Liquids
}

\author{
Z. Baicha 1,2, M.J. Salar-García 2,3,*, V.M. Ortiz-Martínez 2,3,* , F.J. Hernández-Fernández 2,3,*, \\ A.P. de los Ríos ${ }^{3}$, D.P. Maqueda Marín ${ }^{3}$ D , J.A. Collado ${ }^{3}$, F. Tomás-Alonso ${ }^{3}$ and M. El Mahi $^{1}$ \\ 1 Laboratory of Spectroscopy, Molecular Modeling, Materials, Nanomaterials, Water and Environment, \\ Environmental Materials Team, ENSET, Mohammed V University in Rabat, Rabat E-8007, Morocco \\ 2 Department of Chemical and Environmental Engineering, Regional Campus of International Excellence \\ "Campus Mare Nostrum", Technical University of Cartagena, Campus Muralla del Mar, \\ E-30202 Cartagena, Spain \\ 3 Department of Chemical Engineering, Regional Campus of International Excellence \\ "Campus Mare Nostrum", University of Murcia, Campus de Espinardo, E-30100 Murcia, Spain \\ * Correspondence: mariajose.salar@upct.es (M.J.S.-G.); victor.ortiz@upct.es (V.M.O.-M.); \\ fjhernan@um.es (F.J.H.-F.)
}

Received: 25 June 2019; Accepted: 3 August 2019; Published: 16 August 2019

\begin{abstract}
In the last few years, the use of ionic liquid-based membranes has gained importance in a wide variety of separation processes due to the unique properties of ionic liquids. The aim of this work is to analyze the transport of nutrients through polymer inclusion membranes based on different concentrations of methyltrioctylammonium chloride, in order to broaden the application range of these kinds of membranes. Calcium chloride $\left(\mathrm{CaCl}_{2}\right)$ and sodium hydrogen phosphate $\left(\mathrm{Na}_{2} \mathrm{HPO}_{4}\right)$ nutrients were used at the concentration of $1 \mathrm{~g} \cdot \mathrm{L}^{-1}$ in the feeding phase. The evolution of the concentration in the receiving phase over time $(168 \mathrm{~h})$ was monitored and the experimental data fitted to a diffusion-solution transport model. The results show very low permeation values for $\mathrm{CaCl}_{2}$. By contrast, in the case of $\mathrm{Na}_{2} \mathrm{HPO}_{4}$ the permeation values were higher and increase as the amount of ionic liquid in the membrane also increases. The surface of the membranes was characterized before and after being used in the separation process by scanning electron microscopy coupled to energy dispersive X-Ray spectroscopy (SEM-EDX) and elemental mapping analysis. The SEM-EDX images show that the polymer inclusion membranes studied are stable to aqueous solution contacting phases and therefore, they might be used for the selective transport of nutrients in separation processes.
\end{abstract}

Keywords: polymer inclusion membranes; ionic liquids; nutrients; liquid membrane stability; permeation

\section{Introduction}

Over the years, membrane-based processes have attracted much interest because they can be performed under moderate conditions and their energy needs are significantly lower [1]. Reverse osmosis, ultrafiltration, microfiltration, pervaporation, and gas permeation are a few examples of the most common membrane-based processes. In all these cases, the performance of the separation process might be improved by tailoring the membrane properties for the selective separation of a specific compound. One of the current trends for improving the membranes properties involves the use of ionic liquids (ILs) [1].

Ionic liquids are molten salts, which remain liquid at temperatures below $100{ }^{\circ} \mathrm{C}$. They usually consist of an organic cation (imidazolium, pyrrolidinium, pyridinium, etc.) and an 
inorganic (hexafluorophosphate, tetrafluoroborate, chloride, etc.) or organic anion (dicyanamide, bistrifluoromethylsulfonylimde, tosylate, etc.). Their unique properties make them very attractive for a wide variety of chemical processes such as separation or catalysis. They exhibit good chemical and thermal stability along with near-zero vapor pressure. They are considered as environmentally friendly solvents whose properties can be tailored by varying the anion and the cation of their structure in order to be adapted to a specific process [2,3].

ILs have been successfully employed as extraction agents for metal ions, organic compounds, and macromolecules and in liquid/liquid systems [4-7]. However, their immobilization in different kinds of matrixes provides a dual benefit: (i) to obtain stable materials with a minimal content of IL and (ii) the opportunity to reuse the IL at the end of the process. Other benefits of these types of membranes are their simple synthesis process and their low energy requirements. Regarding the membrane properties, the use of ionic liquid in its structure allows us to tailor them in order to be adapted to a specific and selective separation process [8,9]. IL-based membranes can be mainly grouped into: (i) supported ionic liquids membranes (SILMs), (ii) polymer ionic liquid inclusion membranes (PILIMs), (iii) polymerized ionic liquid membranes (PyILMs), and (iv) other ionic liquid/polymer composite materials [10]. SILMs consist of immobilizing the IL into a porous material by using capillary forces. The main drawback of these membranes is the lack of long-term stability caused by the leakage of the IL from the porous. To overcome this limitation, the IL can be immobilized into a polymer matrix where it is completely retained, giving rise to PILIMs. Both the long-term stability as well as the selectivity of this type of membranes has promoted their application in a broad domain. For instance, IL-based membranes have shown promising results in gas separation and metal extraction [11,12]. Another recent use of PILIMs is as separators in microbial fuel cells (MFCs) [13]. Microbial fuel cells use bacteria to convert the chemical energy stored in a specific substrate into electrical energy. Thus far, different kinds of synthetic substrates have been explored, however, complex feedstock such as wastewater is most interesting due to its need for treatment and availability. The main advantage of MFCs over other technologies is that they are able to produce electricity and treat wastewater simultaneously [14]. However, in order to facilitate the commercialization of this technology, it is necessary to reduce the overall cost of the devices as well as improving the energy harvesting. The use of IL-based membranes addresses both challenges by replacing the expensive and sometimes low-efficiency commercial membranes [15]. In recent years, MFCs technology was combined with algae as the oxygen supplier. In this case, bacteria degrade the organic matter in the anodic chamber while algae grow in the cathodic compartment, providing the oxygen necessary for completing the redox reaction on the cathode. Furthermore, algae are able to capture carbon dioxide and the algal biomass produced could be used for the production of added-value compounds [16]. This novel approach could improve the power performance and the wastewater treatment efficiency of MFCs. Moreover, the transport of specific compounds from the anode to the cathode might also help algae growth, reducing the nutrients added to the cathode chamber. The selective transport of nutrients through the membrane will allow us to design a more efficient system for both bioenergy production and wastewater treatment.

In this work, the transport of two nutrients, specifically calcium chloride $\left(\mathrm{CaCl}_{2}\right)$ and sodium hydrogen phosphate $\left(\mathrm{Na}_{2} \mathrm{HPO}_{4}\right)$, through polymer inclusion membranes, based on ammonium-type ionic liquid, was evaluated. The effect of the ionic liquid membrane composition and the nature of the nutrient on the permeability of the membrane was analyzed in-depth. Although the main objective of this work is the application of the results to the design of a double-chamber MFC, the conclusions of the present work might be applied to any field in which the recovery or selective separation of the studied nutrients are of interest. 


\section{Materials and Methods}

\subsection{Preparation of Polymer Inclusion Membranes Based on Ionic Liquids}

Casting method was used in order to prepare polymer inclusion membranes, based on methyltrioctylammonium chloride, $\left[\mathrm{MTOA}^{+}\right]\left[\mathrm{Cl}^{-}\right]$. This ionic liquid was purchased from Sigma-Aldrich-Fluka (purity $>97 \%$ ). This technique allows us to immobilize the ionic liquid in a polymeric matrix, in this case, polyvinyl chloride (PVC) (Sigma-Aldrich-Fluka, St. Louis, MO, USA). The method consists of preparing a mixture based on the selected ionic liquid, the polymer, and an adequate amount of tetrahydrofuran (THF). The solution is stirred until the polymer is totally dissolved. Then, it is poured on a glass ring overnight in order to allow the solvent to evaporate. The final weight of the membranes was fixed at $0.3 \mathrm{~g}$ and two different amounts of ionic liquids were used $(70 \% w / w$ and $30 \% w / w)$ [17]. Table 1 depicts the chemical structure of the ammonium-based ionic as well as the polymer used to synthesize the membranes.

Table 1. Structure of both the ionic liquid and the polymer used to prepare the membranes.

\begin{tabular}{cc}
\hline Compound & Structure \\
\hline $\begin{array}{c}\text { Methyltrioctylammonium } \\
\text { Chloride }\end{array}$ & $\mathrm{H}_{17} \mathrm{C}_{8}-\stackrel{\mathrm{N}^{+}-\mathrm{CH}_{37}}{\mathrm{C}^{-}}$ \\
& $\mathrm{Cl}^{-}$ \\
Polyvinyl Chloride & {$\left[\begin{array}{cc}\mathrm{C} & \mathrm{H} \\
\mathrm{I} & \mathrm{I} \\
\mathrm{C} & -\mathrm{C} \\
\mathrm{I} & \mathrm{I} \\
\mathrm{H} & \mathrm{Cl}\end{array}\right]_{\mathrm{n}}$} \\
\hline
\end{tabular}

\subsection{SEM-EDX and Elemental Mapping Characterization}

The morphological appearance and the chemical composition of the membranes were analyzed, as well as the distribution of the elements of interest on their surface by using a scanning electron microscope (SEM) Hitachi S-3500N (Tokyo, Japan) and a Bruker AXS (MA, USA) for energy-dispersive X-ray (EDX).

The ionic liquid-based membranes were characterized by SEM-EDX and elemental mapping before and after being used for the selective transport of the nutrients.

\subsection{Ion Transport Studies}

The transport of $\mathrm{CaCl}_{2}$ and $\mathrm{Na}_{2} \mathrm{HPO}_{4}$ through the PILIMs was evaluated. The transport studies were performed at $25^{\circ} \mathrm{C}$ by using a glass diffusion cell with two independent compartments of $250 \mathrm{~mL}$ each and separated by the PILIMs (see Figure 1). In each experiment, pure $\mathrm{CaCl}_{2}$ and $\mathrm{Na}_{2} \mathrm{HPO}_{4}$ were used in order to prepare two different feeding solutions with a final concentration of $1 \mathrm{~g} \cdot \mathrm{L}^{-1}$. Pure water was used as the receiving solution in both cases. Substrates, solvents, and other chemicals were purchased with the highest purity available from Sigma-Aldrich-Fluka. Both compartments were mechanically stirred to avoid concentration polarization conditions at the membrane interface. The transport of the anions and cations contained in the feeding phase across the IL-based membranes was analyzed during $168 \mathrm{~h}$. Samples were taken at different time intervals during the operating time and their composition was analyzed by ionic chromatography (850 Professional IC, Metrohm). 


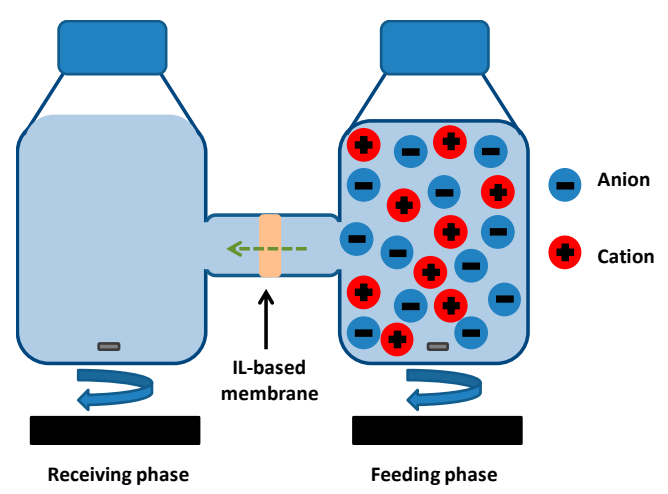

Figure 1. Scheme of the glass diffusion cell set-up used for the nutrient analysis through ionic liquid (IL)-based membranes.

\subsection{Ionic Chromatography}

Ion detection was performed by using an 861 Advanced Compact IC module. Cations $\mathrm{Na}^{+}$and $\mathrm{Ca}^{+2}$ were determined by a Metrosep C4-250 column, whereas $\mathrm{Cl}^{-}$and $\mathrm{HPO}_{4}{ }^{-2}$ anions were detected by a Metrosep A Supp 5-250 column.

\subsection{Calculation of Permeability}

The transport of the nutrients through the IL-based membranes was analyzed in terms of permeability. The average permeability $(\overline{\mathrm{P}})$ was calculated from the slope of Equation (1), which was derived from the application of the solution-diffusion model (see Figure 2) to the transport of nutrients through PILIMs [18].

$$
\ln \left(\frac{C_{0}-2 C_{r}}{C_{0}}\right)=\frac{-2 \overline{\mathrm{P}} A}{V} t
$$

where $C_{0}$ is the initial solute concentration in the feeding phase $\left(\mathrm{mol} \cdot \mathrm{L}^{-1}\right), C_{r}$ the solute concentration in the receiving phase $\left(\mathrm{mol} \cdot \mathrm{L}^{-1}\right), \mathrm{A}$ the membrane area $\left(\mathrm{cm}^{2}\right), V$ is the volume of the compartments $(\mathrm{mL})$ and $t$ the run time (h). All experiments were carried out in duplicate and the mean values are reported.

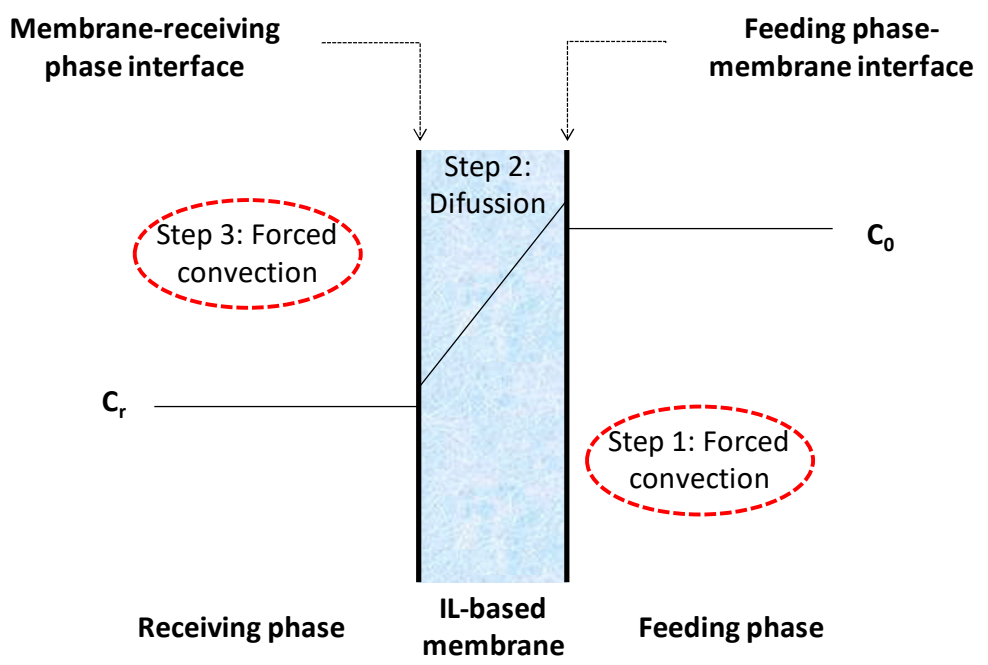

Figure 2. Transport of nutrients through polymer ionic liquid inclusion membranes (PILIMs) based on solution-diffusion model.

In order to evaluate the ability of the different membranes to separate the target compounds, another parameter named average permselectivity of the membrane is defined as follows: 


$$
r \overline{\mathrm{P}}=\frac{\sum_{i}^{n} r P_{i}}{n} \text { with } r P_{i>1}
$$

where $r P_{i}$ is the membrane permselectivity between two compounds and $n$ is the number of the possible combinations of compounds. $r P_{i}$ can be rewritten as follows:

$$
r P_{i}=\frac{P_{A}}{P_{B}}
$$

The average permselectivity $(r \overline{\mathrm{P}})$ of the membranes indicates its efficiency for the separation of a specific compound [18].

\section{Results and Discussion}

\subsection{Polymer Ionic Liquid Inclusion Membrane Characterization before and after Being Used as Separators}

Before the preparation of the PILIMs $(30 \%$ and $70 \% w / w)$, their respective morphology was studied by SEM. SEM micrographs (see Figure $3 A, B$ ) showed a smooth surface. Figure $3 A^{\prime}, B^{\prime}$ show the characterization of the membranes by elemental mapping, demonstrating the homogeneous distribution of the $\mathrm{N}$ (in green) and $\mathrm{Cl}$ (in red) along the membrane surface. Figure $3 \mathrm{~A}, \mathrm{~B}$ also show some stains on the external surface of the membranes. These stains might be an excess of IL since they are highlighted in green color in the mapping images. This color represents the nitrogen and it is only present in the IL structure and not in the PVC (see Figure $3 \mathrm{~A}^{\prime}, \mathrm{B}^{\prime}$ ). The EDX spectra of the membranes (see Figure 4A,B) presented the characteristic peaks assigned to chlorine $(\mathrm{Cl})$ and nitrogen $(\mathrm{N})$ [19]. The presence of these chemical elements corresponds to the chemical formulation of PVC $(\mathrm{Cl})$ and $\left[\mathrm{MTOA}^{+}\right]\left[\mathrm{Cl}^{-}\right](\mathrm{N}$ and $\mathrm{Cl})$, respectively.

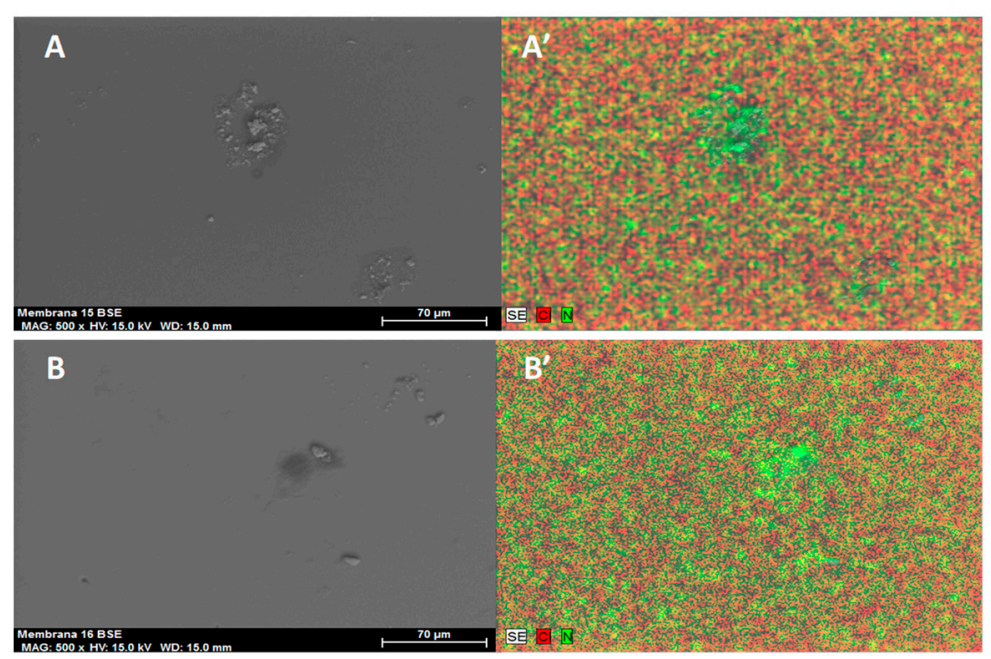

Figure 3. SEM and elemental mapping of membranes containing $70 \% w / w$ of IL $\left(\mathbf{A}, \mathbf{A}^{\prime}\right)$ and membranes containing $30 \% w / w$ of IL (B, $\left.\mathbf{B}^{\prime}\right)$ before being used.

Figures 5-8 show the SEM-EDX and elemental mapping of the membranes containing 30 and $70 \% w / w$ of ionic liquid after being used as separators for each feeding solution $\left(\mathrm{CaCl}_{2}\right.$ and $\mathrm{Na}_{2} \mathrm{HPO}_{4}$, respectively). 

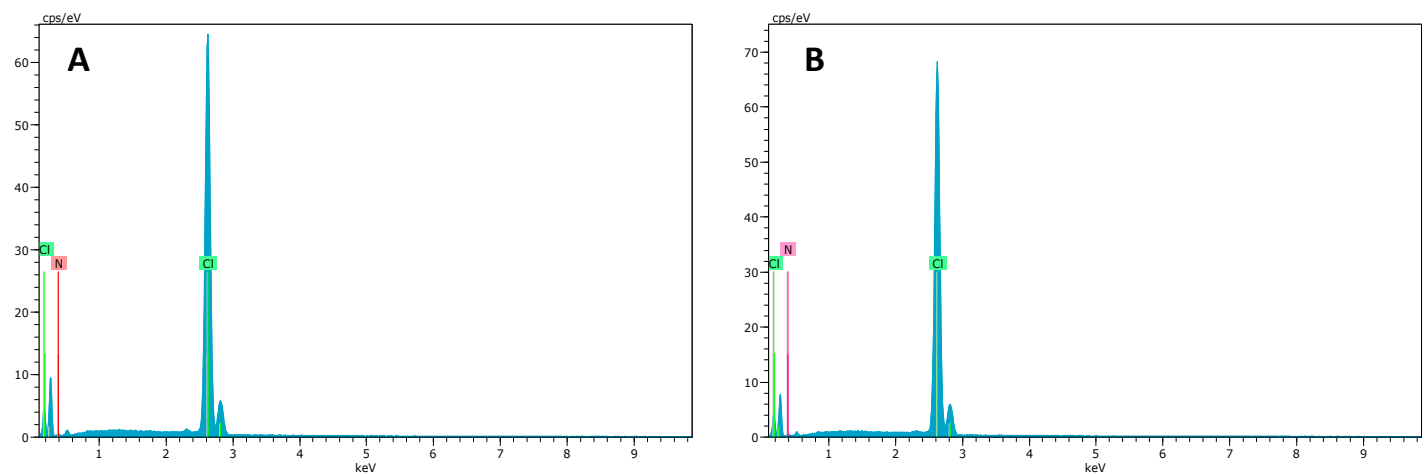

Figure 4. Energy-dispersive X-ray (EDX) analysis of membranes containing 70\% w/w (A) and 30\% $w / w$ of IL (B) before being used.

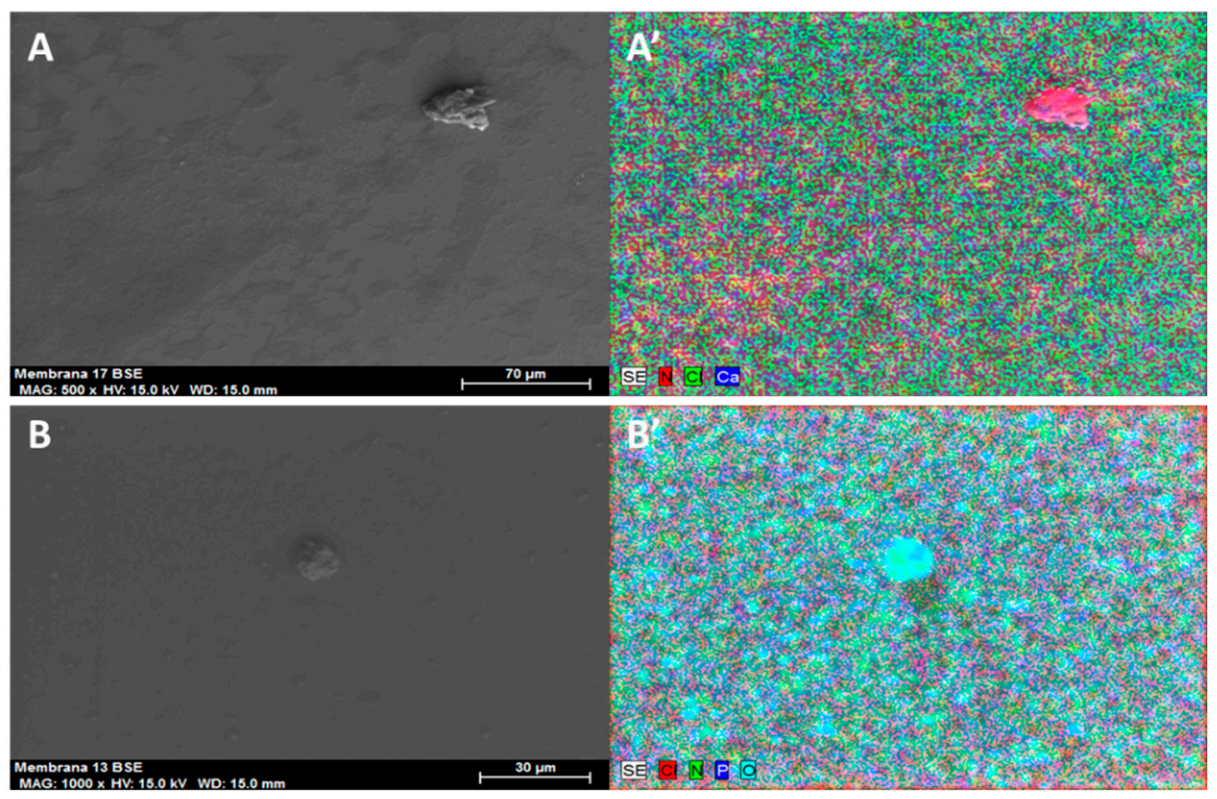

Figure 5. SEM of membranes containing 30\% $w / w$ of IL after being used as separators for each feeding solution: $\mathrm{CaCl}_{2}(\mathbf{A})$ and $\mathrm{Na}_{2} \mathrm{HPO}_{4}(\mathbf{B})$, and elemental mapping: $\mathrm{CaCl}_{2}\left(\mathbf{A}^{\prime}\right)$ and $\mathrm{Na}_{2} \mathrm{HPO}_{4}\left(\mathbf{B}^{\prime}\right)$.
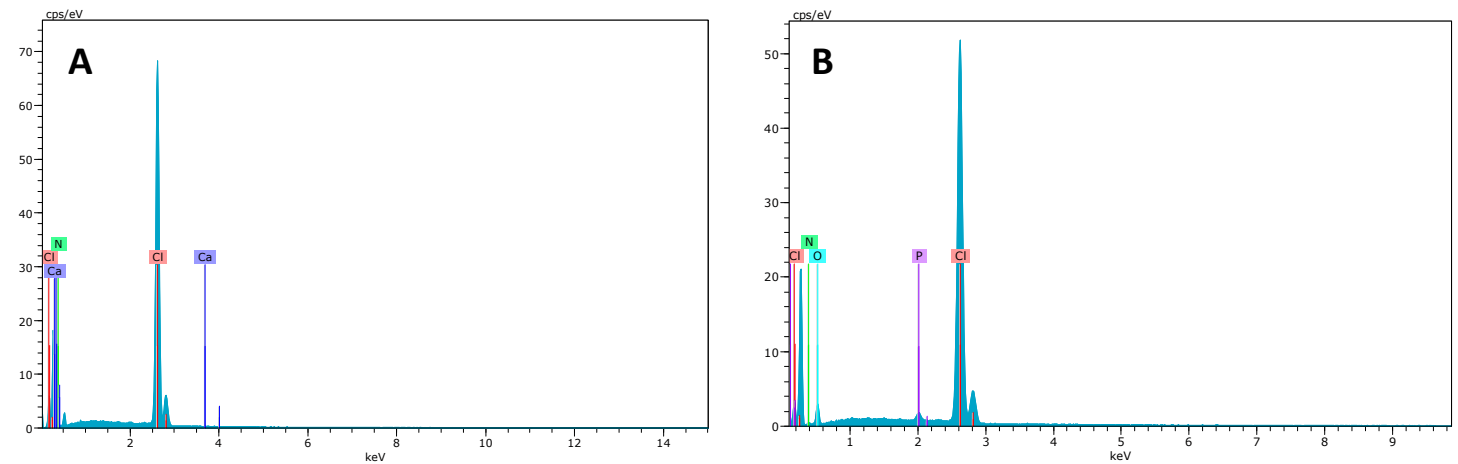

Figure 6. EDX analysis of membranes containing 30\% w/w of IL after being used as separators for each feeding solution: $\mathrm{CaCl}_{2}(\mathbf{A})$ and $\mathrm{Na}_{2} \mathrm{HPO}_{4}(\mathbf{B})$. 

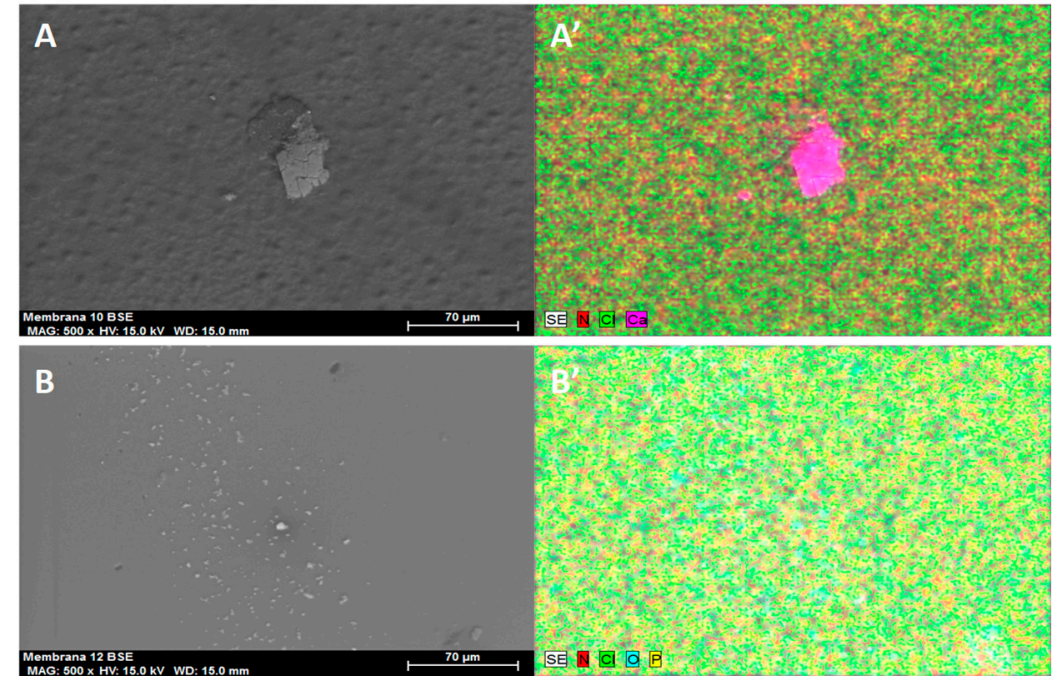

Figure 7. SEM of membranes containing $70 \% w / w$ of IL after being used as separators for each feeding solution: $\mathrm{CaCl}_{2}(\mathbf{A})$ and $\mathrm{Na}_{2} \mathrm{HPO}_{4}(\mathbf{B})$, and elemental mapping: $\mathrm{CaCl}_{2}\left(\mathbf{A}^{\prime}\right)$ and $\mathrm{Na}_{2} \mathrm{HPO}_{4}\left(\mathbf{B}^{\prime}\right)$.
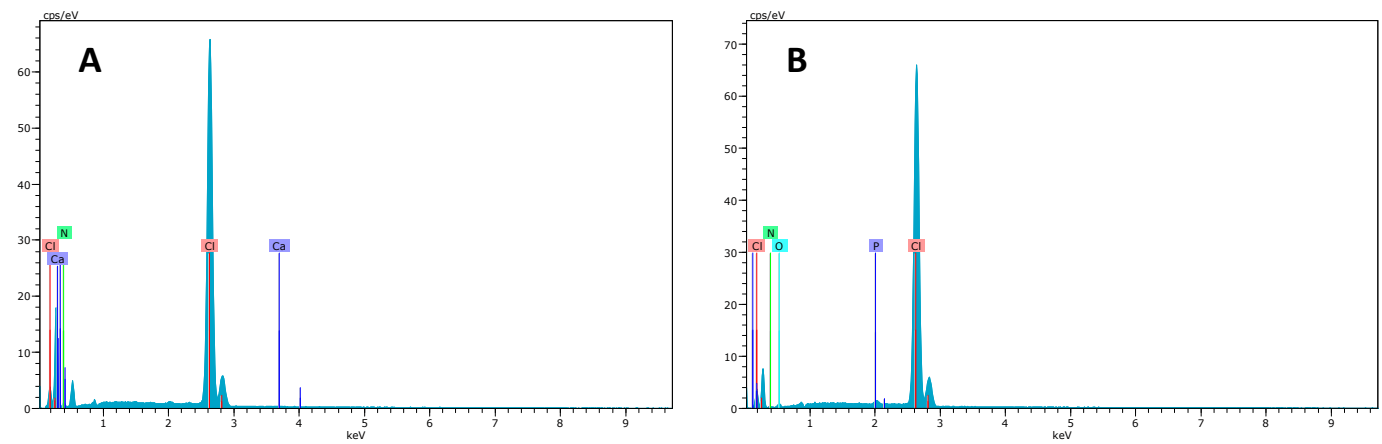

Figure 8. EDX analysis of membranes containing $70 \% w / w$ of IL after being used as separators for each feeding solution: $\mathrm{CaCl}_{2}(\mathbf{A})$ and $\mathrm{Na}_{2} \mathrm{HPO}_{4}(\mathbf{B})$.

As can be seen in Figures 6 and 8, the characteristic peaks of the membrane (N for $\left[\mathrm{MTOA}^{+}\right]\left[\mathrm{Cl}^{-}\right]$ and $\mathrm{Cl}$ for $\mathrm{PVC}$ ) appeared after using it as separator, which indicates the adequate stability of the membrane. In addition to the characteristic peaks of the membranes, other signals belonging to the nutrients studied are also observed. Those are calcium $(\mathrm{Ca})$ and chlorine $(\mathrm{Cl})$ when the nutrient studied is $\mathrm{CaCl}_{2}$ (see Figure $5 \mathrm{~A}^{\prime}$, Figure $6 \mathrm{~A}^{\prime}$, Figure $7 \mathrm{~A}^{\prime}$ and Figure $8 \mathrm{~A}^{\prime}$ ) and sodium $(\mathrm{Na})$, phosphorus $(\mathrm{P})$, and oxygen $(\mathrm{O})$ in the case of the nutrient $\mathrm{Na}_{2} \mathrm{HPO}_{4}$ (see Figure $5 \mathrm{~B}^{\prime}$, Figure $6 \mathrm{~B}^{\prime}$, Figure $7 \mathrm{~B}^{\prime}$ and Figure $8 \mathrm{~B}^{\prime}$ ). These results might be due to that the transported compounds are absorbed in the membrane structure. The SEM images of the PILIMs, after being used in the diffusion cell, are shown in Figures 5 and 7 $(30 \% w / w$ and $70 \% w / w$ of ionic liquid, respectively). In general, it is observed that the smooth surface of the membranes is kept after being used in the diffusion cell. However, as previously commented, the mapping analysis shows some salt deposits such as $\mathrm{CaCl}_{2}$ when the transport of this nutrient was studied through the membrane with $30 \% w / w$ and $70 \%$ of ionic liquid (see Figure $5 \mathrm{~A}^{\prime}$ and Figure $7 \mathrm{~A}^{\prime}$, respectively).

\subsection{Transport Studies of $\mathrm{CaCl}_{2}$ and $\mathrm{Na}_{2} \mathrm{HPO}_{4}$ through Polymer Inclusion Ionic Liquid Membranes}

The permeability of $\mathrm{CaCl}_{2}$ and $\mathrm{Na}_{2} \mathrm{HPO}_{4}$ through polymer inclusion membranes, based on $\left[\mathrm{MTOA}^{+}\right]\left[\mathrm{Cl}^{-}\right]$, was determined. The experimental concentration of the anions and cations in the feeding and receiving phases as a function of the time was monitored, and the permeability of the species was calculated by using the concentrations in the receiving phase (see Figure 9). In this way, the permeability values were calculated from the slopes of the plot of $\ln \left[\left(C_{0}-2 C_{r}\right) / C_{0}\right]$ for each compound 
versus time using Equation (1). As an example, Figure 10 shows the plots used to calculate the permeability of each compound through the membrane based on $70 \% w / w$ of $\left[\mathrm{MTOA}^{+}\right]\left[\mathrm{Cl}^{-}\right]$. Neither Figure 9 nor Figure 10 indicate the correlation coefficients of $\mathrm{Ca}^{+2}$ and $\mathrm{Cl}^{-}$due to the very low values of permeability exhibited by both ions through the membranes studied. Moreover, in the case of the $\mathrm{Cl}^{-}$, the possible release of IL from the membrane could also affect the application of the model selected to the ions' concentration found. The permeability values for each compound through the different PILIMs are shown in Table 2.
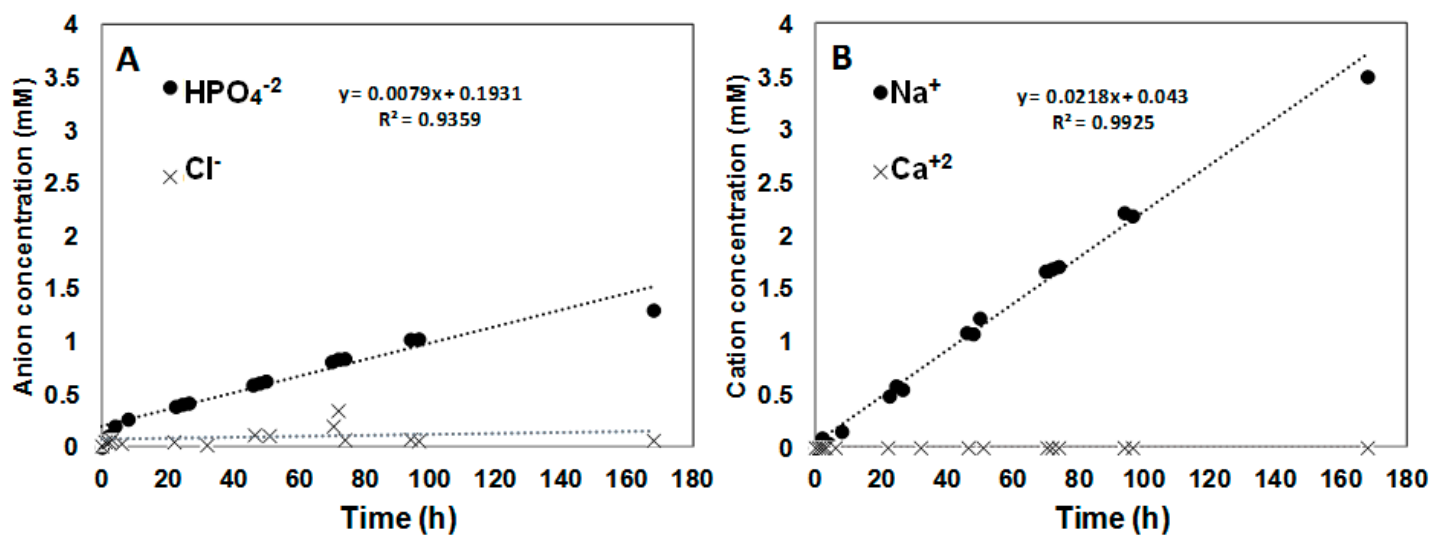

Figure 9. Time courses for the anions (A) and cations (B) of each nutrient in the receiving phase using a PILIM based on $70 \% w / w$ of $\left[\mathrm{MTOA}^{+}\right]\left[\mathrm{Cl}^{-}\right]$.
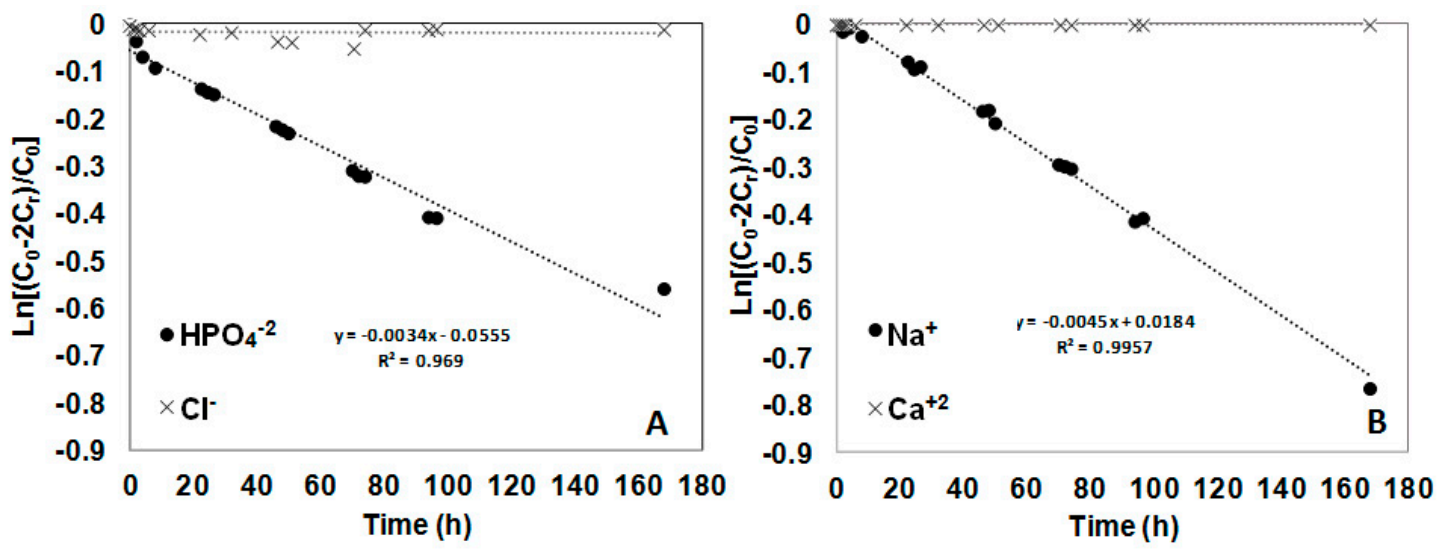

Figure 10. Plot of $\ln \left[\left(\mathrm{C}_{0}-2 \mathrm{C}_{\mathrm{r}}\right) / \mathrm{C}_{0}\right]$ vs. operation time for the transport of the anions $(\mathrm{A})$ and cations (B) of each nutrient through a PILIM based on $70 \% w / w$ of $\left[\mathrm{MTOA}^{+}\right]\left[\mathrm{Cl}^{-}\right]$.

Table 2. Permeability values of the polymer inclusion membranes based on the liquid $\left[\mathrm{MTOA}^{+}\right]\left[\mathrm{Cl}^{-}\right]$ on the transport of $\mathrm{CaCl}_{2}$ and $\mathrm{Na}_{2} \mathrm{HPO}_{4}$.

\begin{tabular}{ccccc}
\hline & \multicolumn{4}{c}{ Permeability $\left(\times \mathbf{1 0}^{\mathbf{6}}{\left.\mathbf{c m} . \mathbf{s}^{-1}\right)}\right.$} \\
\hline Membrane & $\mathbf{N a}^{+}$ & $\mathbf{H P O}_{4}{ }^{2-}$ & $\mathbf{C a}^{+2}$ & $\mathbf{C l}^{-}$ \\
\hline $\mathbf{7 0} \% w / w\left[\mathrm{MTOA}^{+}\right]\left[\mathrm{Cl}^{-}\right]$ & 25.671 & 18.463 & 0.000 & 2.669 \\
$\mathbf{3 0} \% \boldsymbol{w} w\left[\mathrm{MTOA}^{+}\right]\left[\mathrm{Cl}^{-}\right]$ & 4.216 & 5.351 & 0.000 & 1.573 \\
\hline
\end{tabular}

Regarding the permeability values (see Table 2), all ions studied permeated through the membranes, except $\mathrm{Ca}^{+2}$ for which non-permeation was found for both ionic liquid-based membranes $(30 \% \mathrm{w} / \mathrm{w}$ and $70 \% w / w$ of IL). Significant differences in terms of permeation between ions and between the same ion through the different membranes $(30 \% w / w$ and $70 \% w / w$ of IL) were found. As can be seen in Table 2, the permeation increases as the amount of IL in the membrane also increases. These results might confirm that the IL is the active phase of the membrane allowing the transport of a 
specific ion. By contrast, in the case of chloride, anion low permeability values were obtained while non-permeability of $\mathrm{Ca}^{+2}$ was observed. For minimizing that difference, an assay without nutrient in the feeding phase was carried out. This assay was considered as "zero" when the permeation of chloride was calculated. Regarding the permselectivity of the membranes, the average permselectivity was higher in the case of membranes containing $70 \%$ of IL. This result indicates that the higher amount of IL in the membrane structure, the better selective separation capacity (see Table 3). Comparing by pairs, higher values of selectivity were achieved for membranes containing $70 \%$ of IL than for those prepared with $30 \%$. These results indicate the important role of the ionic liquid in the selective separation of the target ions. The selectivity which involves the ion $\mathrm{Ca}^{+2}$ has not been calculated since its permeability was near zero.

Table 3. Permselectivity values of the polymer inclusion membranes based on the liquid $\left[\mathrm{MTOA}^{+}\right]\left[\mathrm{Cl}^{-}\right]$ on the transport of $\mathrm{CaCl}_{2}$ and $\mathrm{Na}_{2} \mathrm{HPO}_{4}$.

\begin{tabular}{ccccc}
\hline \multicolumn{4}{c}{ Permselectivity $\left(\mathbf{r P}_{\mathbf{i}}\right)$} & Average Permselectivity $(\mathbf{r} \overline{\mathbf{P}})$ \\
\hline Membrane & $\mathrm{Na}^{+} / \mathrm{HPO}_{4}{ }^{-2}$ & $\mathbf{N a}^{+} / \mathrm{Cl}^{-}$ & $\mathrm{Cl}^{-} / \mathrm{HPO}_{4}{ }^{-2}$ \\
\hline $\mathbf{7 0} \%_{w / w}\left[\mathrm{MTOA}^{+}\right]\left[\mathrm{Cl}^{-}\right]$ & 1.39 & 9.62 & 6.92 & 5.98 \\
\hline & $\mathrm{HPO}_{4}{ }^{-2} / \mathrm{Na}^{+}$ & $\mathbf{N a}^{+} / \mathrm{Cl}^{-}$ & $\mathbf{H P O}_{4}{ }^{-2} / \mathrm{Cl}^{-}$ \\
\hline $\mathbf{3 0} \%_{w / w}\left[\mathrm{MTOA}^{+}\right]\left[\mathrm{Cl}^{-}\right]$ & 1.27 & 2.68 & 3.4 & 2.45 \\
\hline
\end{tabular}

Some research works reported in literature study the mechanism of water transport through supported liquid membranes (SLM) and liquid membranes (LM) based on imidazolium ionic liquids $\left([\mathrm{CnMIM}+]\left[\mathrm{PF}_{6}{ }^{-}\right]\right)$. They report that the transport might be regulated by the mobility of water microenvironments inside the IL rather than by molecular diffusion through the bulk ionic liquid. These results show a timeline in the transport through membranes caused by the time needed to reach a critical water concentration within the ionic liquid. Water content in ionic liquids was found to be necessary to facilitate the transport through the membrane of small ions, such as $\mathrm{Na}^{+}$and $\mathrm{Cl}^{-}$, with a low affinity towards the ILs. Hence, transport through the SLM could be understood as transport through water microenvironments in the supported liquid membrane [20,21].

In this work, non-permeation was observed for $\mathrm{Ca}^{+2}$ and a higher lag of time was observed for $\mathrm{Cl}^{-}$. As commented above, the permeation value for chloride could be affected by the loss of chloride from the membrane. The low-permeation value of $\mathrm{Ca}^{+2}$ and $\mathrm{Cl}^{-}$might be due to their low solubility in the ionic liquid phase of the membrane. The water solubility in ionic liquids was studied by Freire et al. (2007) [22]. The authors found that the solubility of water follows the next sequence $\left[\mathrm{BIMIM}^{+}\right]\left[\mathrm{PF}_{6}{ }^{-}\right]>\left[\mathrm{HIMIM}^{+}\right]\left[\mathrm{PF}_{6}{ }^{-}\right]>\left[\mathrm{OIMIM}^{+}\right]\left[\mathrm{PF}_{6}{ }^{-}\right]>\left[\mathrm{MTOA}^{+}\right]\left[\mathrm{Cl}^{-}\right]$. In our case, the forming of a water microenvironment in the ionic liquid would be more difficult because of the low water solubility of $[\mathrm{MTOA}+]\left[\mathrm{Cl}^{-}\right]$. For that reason, low or negligible permeation of small ions such as $\mathrm{Ca}^{+2}$ and $\mathrm{Cl}^{-}$was observed. In the case of $\mathrm{Na}_{2} \mathrm{HPO}_{4}$, the permeability could be explained by solvent ion-pair extraction and ion exchange, as is it explained below.

It should also be considered that the permeability values depend on the method used for the immobilization of the ionic liquid on the supporting material. SILMs usually allow high permeability values, however, their stability is lower compared with polymer inclusion membranes, where the ionic liquids are trapped in the polymer matrix, as in this case [23]. The stability of the membranes is usually a critical factor for large-scale applications of membrane technology.

With regard to the transfer mechanism of ions through ionic liquid membranes, the ionic nature of the ionic liquid can result in a variety of extraction mechanisms, including solvent ion-pair extraction, ion exchange, transport through water microenvironment, and simultaneous combinations of these. The ion-pair extraction mechanism depends on the solubilization of the salt on the ionic liquids, whereas the ion exchange-based mechanism relies on the exchange capacity of the ionic liquid phase. Regarding the transport through water microenvironment, as previously commented, it depends on 
the water solubility on the ionic liquids. The main mechanism will depend on the importance of this over the rest of the mechanisms and should be studied for each pair of nutrient and ionic liquid phase. An in-depth understanding of the transfer mechanism is of primary importance for establishing a predictive model that might be used in practical operations. According to the preliminary results obtained in the present work, it might be possible that the primary mechanism is by solvent ion-pair extraction, however, other mechanisms could also be involved in the process. In order to achieve a better understanding of the transfer mechanisms, further work is currently being carried out.

\section{Conclusions}

The aim of this work is to analyze the transport of nutrients such as $\mathrm{CaCl}_{2}$ and $\mathrm{Na}_{2} \mathrm{HPO}_{4}$ through polymer inclusion membranes based on ammonium-based IL. To the best of the authors' knowledge, the existing literature that focuses on this research field is limited or non-existent. The results show that polymer inclusion membranes containing $\left[\mathrm{MTOA}^{+}\right]\left[\mathrm{Cl}^{-}\right]$are stable towards an aqueous solution of the studied nutrients. In the case of $\mathrm{CaCl}_{2}$, it showed the least permeation due to its low solubility in the ionic liquid $\left[\mathrm{MTOA}^{+}\right]\left[\mathrm{Cl}^{-}\right]$. By contrast, $\mathrm{Na}_{2} \mathrm{HPO}_{4}$ was more permeable and its permeation increased as the amount of IL in the membrane also increased. The results reported in this work could be applied to different fields such as separation and purification of salt mixtures. This study would allow the efficient design of a two-chamber microbial fuel cell, which involves IL-based membrane technology and algae. The permeation values of different nutrients would also allow us to decide whether the nutrients should be added in the same chamber that microalgae or in the opposite chamber. Furthermore, the results obtained open new fields where polymer ionic liquid membrane might be applied.

Author Contributions: Investigation: M.J.S.-G., V.M.O.-M., Z.B., D.P.M.M. and J.A.C. Data curation: D.P.M.M. Writing-original draft: M.J.S.-G. Writing-review and editing: F.J.H.-F. and M.J.S-G. Supervision: F.J.H.-F., A.P.d.1.R. and F.T.-A. Funding adquisition: F.J.H.-F., A.P.d.1.R. and M.E.M.

Funding: This research received external funding by the Spanish Ministry of Economy and Competitiveness (MINECO) (Grant number: RTI2018-099011-B-I00) and Séneca Foundation (Grant number: 20957/PI/18). Zakarya Baicha thanks to Erasmus+ program (Ref: 2015-1-ES01-KA107-014539) the opportunity to collaborate with the Technical University of Cartagena.

Conflicts of Interest: The authors declare no conflict of interest.

\section{References}

1. Ortiz, I.; Bringas, E.; Samaniego, H.; San Román, M.F.; Urtiaga, A. Membrane processes for the efficient recovery of anionic pollutants. Desalination 2006, 193, 375-380. [CrossRef]

2. Lozano, L.J.; Godínez, C.; de los Ríos, A.P.; Hernández-Fernández, F.J.; Sánchez-Segado, S.; Alguacil, F.J. Recent advances in supported ionic liquid membrane technology. J. Membr. Sci. 2011, 376, 1-14. [CrossRef]

3. Plechkova, N.V.; Seddon, K.R. Applications of ionic liquids in the chemical industry. Chem. Soc. Rev. 2008, 37, 123-150. [CrossRef] [PubMed]

4. de los Ríos, A.P.; Hernández-Fernández, F.J.; Lozano, L.J.; Sánchez, S.; Moreno, J.I.; Godínez, C. Removal of Metal Ions from Aqueous Solutions by Extraction with Ionic Liquids. J. Chem. Eng. Data 2010, 55, $605-608$. [CrossRef]

5. de los Ríos, A.P.; Hernández-Fernández, F.J.; Alguacil, F.J.; Lozano, L.J.; Ginestá, A.; García-Díaz, I.; Sánchez-Segado, S.; López, F.A.; Godínez, C. On the use of imidazolium and ammonium-based ionic liquids as green solvents for the selective recovery of $\mathrm{Zn}(\mathrm{II}), \mathrm{Cd}(\mathrm{II}), \mathrm{Cu}(\mathrm{II})$ and $\mathrm{Fe}(\mathrm{III})$ from hydrochloride aqueous solutions. Sep. Purif. Technol. 2012, 97, 150-157. [CrossRef]

6. de los Ríos, A.P.; Hernández-Fernández, F.J.; Tomás-Alonso, F.; Rubio, M.; Gómez, D.; Víllora, G. On the importance of the nature of the ionic liquids in the selective simultaneous separation of the substrates and products of a transesterification reaction through supported ionic liquid membranes. J. Membr. Sci. 2008, 307, 233-238. [CrossRef]

7. Soto, A.; Arce, A.; Khoshkbarchi, M.K. Partitioning of antibiotics in a two-liquid phase system formed by water and a room temperature ionic liquid. Sep. Purif. Technol. 2005, 44, 242-246. [CrossRef] 
8. de los Ríos, A.P.; Hernández-Fernández, F.J.; Presa, H.; Gómez, D.; Víllora, G. Tailoring supported ionic liquid membranes for the selective separation of transesterification reaction compounds. J. Membr. Sci. 2009, 328, 81-85.

9. Noble, R.D.; Gin, D.L. Perspective on ionic liquids and ionic liquid membranes. J. Membr. Sci. 2011, 369, 1-4. [CrossRef]

10. Dai, Z.; Noble, R.D.; Gin, D.L.; Zhang, X.; Deng, L. Combination of ionic liquids with membrane technology: A new approach for $\mathrm{CO}_{2}$ separation. J. Membr. Sci. 2016, 497, 1-20. [CrossRef]

11. Deng, J.; Bai, L.; Zeng, S.; Zhang, X.; Nie, Y.; Deng, L.; Zhang, S. Ether-functionalized ionic liquid based composite membranes for carbon dioxide separation. RSC Adv. 2016, 6, 45184-45192. [CrossRef]

12. Guo, L.; Zhang, J.; Zhang, D.; Liu, Y.; Deng, Y.; Chen, J. Preparation of poly (vinylidene fluoride-co-tetrafluoroethylene)-based polymer inclusion membrane using bifunctional ionic liquid extractant for Cr(VI) transport. Ind. Eng. Chem. Res. 2012, 51, 2714-2722. [CrossRef]

13. Hernandez-Fernandez, F.J.; de Los Rios, A.P.; Salar-Garcia, M.J.; Ortiz-Martinez, V.M.; Lozano-Blanco, L.J.; Godinez, C.; Tomas-Alonso, F.; Quesada-Medina, J. Recent progress and perspectives in microbial fuel cells for bioenergy generation and wastewater treatment. Fuel Process. Technol. 2015, 138, 284-297. [CrossRef]

14. Pandey, P.; Shinde, V.N.; Deopurkar, R.L.; Kale, S.P.; Patil, S.A.; Pant, D. Recent advances in the use of different substrates in microbial fuel cells toward wastewater treatment and simultaneous energy recovery. Appl. Energy 2016, 168, 706-723. [CrossRef]

15. Ortiz-Martínez, V.M.; Salar-García, M.J.; Hernández-Fernández, F.J.; de los Ríos, A.P. Development and characterization of a new embedded ionic liquid based membrane-cathode assembly for its application in single chamber microbial fuel cells. Energy 2015, 93, 1748-1757.

16. Baicha, Z.; Salar-García, M.J.; Ortiz-Martínez, V.M.; Hernández-Fernández, F.J.; de los Ríos, A.P.; Labjar, N.; Lotfi, E.; Elmahi, M. A critical review on microalgae as an alternative source for bioenergy production: A promising low cost substrate for microbial fuel cells. Fuel Process. Technol. 2016, 154, 104-116. [CrossRef]

17. Salar-García, M.J.; Ortiz-Martínez, V.M.; de los Ríos, A.P.; Hernández-Fernández, F.J. A method based on impedance spectroscopy for predicting the behavior of novel ionic liquid-polymer inclusion membranes in microbial fuel cells. Energy 2015, 89, 648-654. [CrossRef]

18. Hernandez Fernandez, F.; de los Rios, A.P.; Rubio, M.; Tomas Alonso, F.; Gomez, D.; Villora, G. A novel application of supported liquid membranes based on ionic liquids to the selective simultaneous separation of the substrates and products of a transesterification reaction. J. Membr. Sci. 2007, 293, 73-80. [CrossRef]

19. de los Ríos, A.P.; Hernández-Fernández, F.J; Tomás-Alonso, F.; Palacios, J.M.; Gómez, D.; Rubio, M.; Víllora, G. A SEM-EDX study of highly stable supported liquid membranes based on ionic liquids. J. Membr. Sci. 2007, 300, 88-94.

20. Fortunato, R.; González-Muñoz, M.J.; Kubasiewicz, M.; Luque, S.; Alvarez, J.R.; Afonso, C.A.M.; Coelhoso, I.M.; Crespo, J.G. Liquid membranes using ionic liquids: The influence of water on solute transport. J. Membr. Sci. 2005, 249, 153-162. [CrossRef]

21. Fortunato, R.; Afonso, C.A.M.; Reis, M.A.M.; Crespo, J.G. Supported liquid membranes using ionic liquids: Study of stability and transport mechanisms. J. Membr. Sci. 2004, 242, 197-209. [CrossRef]

22. Freire, M.G.; Santos, L.M.N.B.F.; Fernandes, A.M.; Coutinho, J.A.P.; Marrucho, I.M. An overview of the mutual solubilities of water-imidazolium-based ionic liquids systems. Fluid Phase Equilib. 2007, 261, 449-454. [CrossRef]

23. Tomás-Alonso, F.; Rubio, A.M.; Giménez, A.; de los Ríos, A.P.; Salar-García, M.J.; Ortiz-Martínez, V.M.; Hernández-Fernández, F.J. Influence of ionic liquid composition on the stability of polyvinyl chloride-based ionic liquid inclusion membranes in aqueous solution. AIChE J. 2017, 63, 770-780. [CrossRef]

C 2019 by the authors. Licensee MDPI, Basel, Switzerland. This article is an open access article distributed under the terms and conditions of the Creative Commons Attribution (CC BY) license (http://creativecommons.org/licenses/by/4.0/). 